\title{
Sodium Butyrate Plus EGF and PDGF-BB Aids Cutaneous Wound Healing in Diabetic Mice
}

\author{
Rohini Keshava ${ }^{1,2}$ and Rajalakshmi Gope ${ }^{1}$ \\ ${ }^{1}$ Department of Human Genetics, NIMHANS, Bangalore 560029, India \\ ${ }^{2}$ Department of Studies in Sericulture/Life Sciences, Bangalore University, Bangalore 560056, India \\ Correspondence should be addressed to Rajalakshmi Gope; rlgope@gmail.com
}

Received 10 August 2015; Revised 13 October 2015; Accepted 13 October 2015

Academic Editor: Paul J. Higgins

Copyright (c) 2015 R. Keshava and R. Gope. This is an open access article distributed under the Creative Commons Attribution License, which permits unrestricted use, distribution, and reproduction in any medium, provided the original work is properly cited.

Topical application of growth factors is known to aid defective and/or delayed wound healing in diabetic patients. In this study, the effect of topical application of sodium butyrate (Na-Bu), EGF, and PDGF-BB was analysed on the acute cutaneous wound healing in streptozotocin (STZ) induced diabetic mouse model. Two cutaneous wounds were created, one on each of the dorsolateral sides of the diabetic mice. Na-Bu, EGF, and PDGF-BB were applied to the wound either individually or in various combinations. The wound healing was monitored visually and scored as percentage wound closure. The tissue samples were collected from the wound site at 1, 7, and 14 days after wounding from the treated and untreated diabetic wounds and analysed for the levels of EGF-R, $\beta$ PDGF-R, HDAC1, p21, and phosphorylated and hypophosphorylated pRb proteins. Our results indicate that application of EGF plus PDGF-BB at the initial stages followed by subsequent addition of $\mathrm{Na}-\mathrm{Bu}$ along with these growth factors helps wound healing in diabetic mice. It appears that, in addition to cell proliferative agents, a cell differentiation agent, $\mathrm{Na}-\mathrm{Bu}$, is necessary for diabetic wound healing. Topical application of EGF plus PDGF-BB along with $\mathrm{Na}-\mathrm{Bu}$ could be developed as therapeutic agents to treat and manage human diabetic wounds.

\section{Introduction}

Diabetes is a common chronic metabolic disorder and is characterised by hyperglycaemia and loss of glucose homeostasis. Patients with diabetes suffer from nonhealing chronic wound, especially foot ulcers, which remains as a global burden even after rigorous treatments with available means $[1,2]$. Topical application of growth factors, epidermal growth factor (EGF), and platelet-derived growth factor-BB (PDGFBB) accelerated wound healing process in normal cases [3-5] and their positive effects are also shown in diabetic wound healing to certain extent [6-10].

Streptozotocin (STZ) produces mild to severe diabetes in a dose-dependent manner when it is given as intravenous (i.v.) or intraperitoneal (i.p.) injections in animal model. Therefore, STZ induced diabetic animals are used to study diabetes related biological properties including wound healing [11].

Sodium butyrate $(\mathrm{Na}-\mathrm{Bu})$ is a nontoxic, naturally occurring fatty acid and it relieves epithelial inflammation [12].
$\mathrm{Na}-\mathrm{Bu}$ induces cell differentiation [13] and is also an inhibitor of histone deacetylase (HDAC) $[14,15]$. In this study, the effect of $\mathrm{Na}-\mathrm{Bu}$ along with the growth factors EGF and PDGF-BB on the cutaneous wound healing process was assessed in STZ induced diabetic mice model. The results indicate that $\mathrm{Na}-\mathrm{Bu}$ when provided along with growth factors can aid cutaneous wound healing in diabetic mice. Our data also shows that $\mathrm{Na}-\mathrm{Bu}$ might be necessary to induce cell differentiation during diabetic wound healing process. It appears that, in addition to cell proliferative agents such as growth factors, cell differentiation agent like $\mathrm{Na}-\mathrm{Bu}$ is mandatory for efficient healing of diabetic wound. Use of growth factors plus $\mathrm{Na}-\mathrm{Bu}$ in a time-bound manner could be developed as a therapeutic agent to manage/treat diabetic wound in human.

\section{Materials and Methods}

2.1. Experimental Mice Model. This study was approved by the National Institute of Mental Health and Neurosciences 
TABLE 1: Details of growth factors, $\mathrm{Na}-\mathrm{Bu}$, and the various antibodies used in this study.

\begin{tabular}{|c|c|c|c|c|}
\hline Product & Supplier & Product number & $\begin{array}{l}\text { Molecular weight of } \\
\text { the band in western } \\
\text { blots }\end{array}$ & $\begin{array}{c}\text { Final } \\
\text { concentration/dilution } \\
\text { (for antibody) used }\end{array}$ \\
\hline EGF & $\begin{array}{c}\text { Sigma-Aldrich, St. Louis, MO, } \\
\text { USA }\end{array}$ & E-6135 & - & $10 \mathrm{ng}$ \\
\hline PDGF-BB & $\begin{array}{c}\text { Sigma-Aldrich, St. Louis, MO, } \\
\text { USA }\end{array}$ & P-3201 & - & $15 \mathrm{ng}$ \\
\hline $\begin{array}{l}\text { Sodium butyrate } \\
\text { (n-butyric acid, sodium } \\
\text { salt) }\end{array}$ & $\begin{array}{c}\text { Sigma-Aldrich, St. Louis, MO, } \\
\text { USA }\end{array}$ & B-5887 & - & $2 \mathrm{mM}$ \\
\hline $\begin{array}{l}\text { Anti-EGF-R antibody } \\
\text { Ab-6 }\end{array}$ & $\begin{array}{l}\text { Oncogene Research Product, } \\
\text { Boston, MA, USA }\end{array}$ & Catalogue number PC98 & $185 \mathrm{kDa}$ & $1: 1000$ \\
\hline Anti- $\beta$-PDGF-R antibody & $\begin{array}{c}\text { BD Biosciences (BD } \\
\text { Pharmingen), Singapore }\end{array}$ & $\begin{array}{c}\text { Catalogue number } 554288 \\
\text { (BD Biosciences) } \\
\text { 15746E (BD Pharmingen) }\end{array}$ & $\begin{array}{l}180 \mathrm{kDa} \text { major; } \\
160 \mathrm{kDa} \text { minor }\end{array}$ & $1: 1000$ \\
\hline Anti-HDAC1 antibody & $\begin{array}{c}\text { Sigma-Aldrich, St. Louis, MO, } \\
\text { USA }\end{array}$ & $\mathrm{H} 3284$ & $65 \mathrm{kDa}$ & $1: 2000$ \\
\hline Anti-P21 ${ }^{\text {WAF1/Cipl }}$ antibody & $\begin{array}{c}\text { Sigma-Aldrich, St. Louis, MO, } \\
\text { USA }\end{array}$ & P1484 & $21 \mathrm{kDa}$ & $1: 1000$ \\
\hline Anti-pRb antibody & $\begin{array}{l}\text { Santa Cruz Biotechnology, } \\
\text { Inc., Santa Cruz, CA, USA }\end{array}$ & $\mathrm{Rb}(\mathrm{Rb} 1): \mathrm{sc}-73598$ & 110 to $114 \mathrm{kDa}$ & $1: 500$ \\
\hline$\gamma$-tubulin antibody & $\begin{array}{c}\text { Sigma-Aldrich, St. Louis, MO, } \\
\text { USA }\end{array}$ & T5326 & $50 \mathrm{kDa}$ & $1: 1000$ \\
\hline $\begin{array}{l}\text { Alkaline phosphatase } \\
\text { conjugated protein A } \\
\text { (secondary antibody) }\end{array}$ & Calbiochem, Nottingham, UK & 539251 & - & $1: 1000$ \\
\hline
\end{tabular}

(NIMHANS) Animal Ethics Committee, certificate number AEC/50/314/HG. Four-week-old male Swiss albino mice were obtained from Central Animal Research Facility (CARF), NIMHANS, Bangalore, India. They were kept in polypropylene cages in a well-ventilated experimental room at $25-30^{\circ} \mathrm{C}$, relative humidity of 40-60\%, and 12-hour light/dark cycle for an additional 2 weeks for acclimatization. Before wounding, 5 mice were placed in each cage and after wounding single mouse was placed in each cage. The mice were fed standard pelleted food from Godrej India Ltd., Mumbai, India, and water ad libitum. The diet consisted of approximately $70 \%$ carbohydrate, $20 \%$ protein, $7 \%$ fat, and $3 \%$ salts and other essential vitamins and minerals [3-5].

2.2. Streptozotocin-Induced Diabetes. Streptozotocin (STZ) was obtained from Sigma-Aldrich, St. Louis, USA. Fresh STZ was prepared every time and used within 5-10 minutes. Briefly, $10 \mathrm{mg} / \mathrm{mL}$ STZ stock was prepared fresh in cold $0.01 \mathrm{M}$ citrate buffer $\mathrm{pH}$ 4.5. Just before injection, the stock solution was diluted to a concentration of $1 \mathrm{mg}$ STZ in $200 \mu \mathrm{L}$ of the same citrate buffer. Six-week-old mice were starved for 20 hours prior to the first injection of STZ. Appropriate volume of STZ depending on the body weight of each mouse was injected intraperitoneally each day for 5 consecutive days. In general, $1 \mathrm{mg} \mathrm{STZ}$ in $200 \mu \mathrm{L}$ of citrate buffer was injected in a mouse weighing approximately $25 \mathrm{~g}$ which equals $40 \mathrm{mg}$ STZ/kg body weight [11]. The control group was injected with $200 \mu \mathrm{L}$ of citrate buffer alone. The blood glucose level was measured weekly from the last day of STZ injection.
The blood samples were collected from the tail vein and deproteinized, and the glucose level was estimated spectrophotometrically by glucose oxidase/peroxidase method [16]. For quick estimation of glucose level, a glucometer kit, Accu-Chek, from Hoffman-La Roche (India) was used.

2.3. Wounding. The wounds were created ten days after the last injection of STZ. Approximately $1 \mathrm{~cm}$ long full thickness wounds were created on both of the dorsolateral sides of each mouse. Briefly, the mice were anesthetised individually with Halothane-soaked cotton (Piramal Healthcare Limited, India), in a glass jar with loose fitted, holed lid. The surface of the mice was cleaned with ethanol, hairs were removed, and two wounds measuring $1 \mathrm{~cm}$ long, one on each of the dorsolateral sides, were created with a sharp surgical blade [3-5].

2.4. Growth Factors and $\mathrm{Na}-\mathrm{Bu}$ Treatments. The details of growth factors used in this experiment are given in Table 1. Recombinant human PDGF-BB and recombinant mouse EGF were obtained from Sigma-Aldrich (St. Louis, MO, USA) as lyophilised powder and they were reconstituted in a solution containing $4 \mathrm{mM} \mathrm{HCL}$ and $0.1 \%$ Bovine Serum Albumin (BSA) according to the protocol given by the supplier. Aliquots of appropriate volumes were stored at $-20^{\circ} \mathrm{C}$ and they were thawed and used only once [3-5]. A stock solution of $200 \mathrm{mM} \mathrm{Na}-\mathrm{Bu}$ was prepared in $1 \mathrm{~mL}$ water as described previously [13, 17]. Optimum concentrations of growth factors EGF (10 ng) and PDGF-BB (15 ng) and Na-Bu 
TABLE 2: Time-line for STZ treatment, wounding, topical application of growth factor(s) and Na-Bu, and tissue harvest.

\begin{tabular}{lcccccccccccccccc}
\hline Day 0 & $\begin{array}{c}\text { D1 } \\
\text { to }\end{array}$ & $\begin{array}{c}\text { D6 } \\
\text { to }\end{array}$ & D16 & D17 & D18 & D19 & D20 & D21 & D22 & D23 & D24 & D25 & D26 & D27 & D28 & D29 \\
& D5 & D15 & W1 & W2 & W3 & W4 & W5 & W6 & W7 & W8 & W9 & W10 & W11 & W12 & W13 & W14 \\
\hline $\begin{array}{l}\text { 20h } \\
\text { STR }\end{array}$ & STZ & - & TT & TT & TT & TT & TT & TT & TT & TT & TT & TT & TT & TT & TT & TT \\
\hline G0 & G1 & G7 & G16 & & & & & & G22 & & & & & \\
\hline
\end{tabular}

Day 0 is the beginning of the experiments. The animals were 6 weeks old and they were starved (STR) for $20 \mathrm{~h}$ prior to the induction of diabetes. STZ, daily injection of streptozotocin at a concentration of $40 \mathrm{mg} / \mathrm{Kg}$ body weight for consecutive 5 days (D1 to D5). Ten days (D6 to D15) after the last STZ injection, the wounds (W) were created and the day of the wounding is taken as W1; TT, various topical treatments as given in Table 4. G, measurement of glucose levels on the days after beginning the experiment; $\mathrm{TH}$, days when the tissues were harvested for western blotting.

(2 mM) [3-5] were applied directly using a micropipette to the wound as described previously [3-5]. A schematic representation of the time course of STZ injection, wounding, growth factor and $\mathrm{Na}-\mathrm{Bu}$ application, glucose estimation, and tissue harvest is given in Table 2. The growth factors of appropriate concentrations in $10 \mu \mathrm{L}$ volume were applied immediately after wounding to each set of 6 mice as follows: (i) a set of nondiabetic mice were kept as control; (ii) a set of STZ injected, untreated mice were kept as diabetic control; the wounds of these two groups were treated daily with $10 \mu \mathrm{L}$ of the diluent used to reconstitute growth factors; the remaining sets of experimental mice were treated daily as follows: (iii) $2 \mathrm{mM} \mathrm{Na}-\mathrm{Bu}$ for 14 days; (iv) $10 \mathrm{ng}$ of EGF for 14 days; (v) $10 \mathrm{ng}$ EGF for the first 2 days followed by $10 \mathrm{ng}$ EGF + 2 mM Na-Bu for the next 12 days; (vi) 15 ng PDGF-BB for 14 days; (vii) $15 \mathrm{ng}$ PDGF-BB for the first 2 days followed by $15 \mathrm{ng}$ PDGF-BB $+2 \mathrm{mM} \mathrm{Na}-\mathrm{Bu}$ for the next 12 days; (viii) 10 ng EGF + 15 ng PDGF-BB for 14 days; (ix) 10 ng EGF + 15 ng PDGF-BB for the first 2 days followed by these growth factors plus $2 \mathrm{mM} \mathrm{Na}$-Bu for the next 12 days.

2.5. Monitoring. The wounds were monitored daily and scored visually for wound closure and new growth of irregular mass of granular tissues. The wound closure was measured and expressed as percentage.

2.6. Tissue Sample Collection and Lysis. The experimental and control groups consisted of 6 mice each. The day of wounding was considered as day 1 . The tissues from the wound sites were collected on days 1,7 , and 14 after wounding. The day 1 samples were collected after wounding followed by respective treatments for approximately 30 minutes to 1 hour (Table 4). The pooled tissue samples from 2 mice were suspended in $100 \mu \mathrm{L}$ of lysis buffer consisting of $10 \mathrm{mM}$ Tris$\mathrm{HCl}, \mathrm{pH}$ 7.0, $150 \mathrm{mM} \mathrm{NaCl}, 5 \mathrm{mM}$ EDTA, $1.2 \%$ Triton X-100, $2 \mathrm{mM}$ phenyl methyl sulfonyl fluoride (PMSF), $0.15 \mathrm{U} / \mathrm{mL}$ aprotinin, and $10 \mu \mathrm{g} / \mathrm{mL}$ leupeptin (Sigma-Aldrich, St. Louis, MO, USA). The tissues were homogenised on ice using a Polytron (Kinematica, Switzerland) 30 seconds $\times 5$ with 1 minute cooling in between strokes. The lysates were clarified by centrifugation at $8,000 \mathrm{~g}$ for 10 minutes at $4^{\circ} \mathrm{C}$. The protein contents were quantified spectrophotometrically from the clear supernatants and analysed by western blotting.
2.7. Western Blotting. One hundred fifty micrograms of tissue lysates in $10 \mu \mathrm{L}$ volume was mixed with $10 \mu \mathrm{L}$ of protein sample buffer (sc-24945, Santa Cruz, Biotechnology, CA, USA), subjected to separation on a 7.5\% SDS-poly acrylamide gel (PAGE) and transferred to PVDF membrane (SigmaAldrich, St. Louis, USA) using a Bio-Rad (Australia) semidry blotter. The nonspecific binding sites on the membrane were blocked in a buffer with BSA, incubated for $2 \mathrm{hrs}$ in primary antibody, and washed and incubated with AP-conjugated secondary antibody $(1: 1000)$ for 1 hour at room temperature on a rocker platform. Details of the antibodies and dilutions are given in Table 1 . Then, the membranes were washed and the bands were visualised with 1-Step NBT/BCIP (Pierce, Rockford, IL, USA) according to the protocol provided by the supplier. The band intensities were calculated from the membranes with Bio-Rad Gel-Doc system with quantity one software. The Broad Range Marker was used for molecular weight determination (sc-2361, Santa Cruz Biotechnology, California, USA). Duplicate gels were run and one of them was incubated with $\gamma$-tubulin primary antibody and used as internal loading control $[13,17]$.

2.8. Data Analysis. The software Statistical Package for Social Sciences (SPSS) version 16 was used for data analysis. The data for glucose level in blood are obtained from three sets of experiments and expressed as mean \pm standard errors of mean (SEM). The levels of EGF-R, PDGF-R, and HDAC1 proteins in the untreated, nondiabetic control mice were normalised to the $\gamma$-tubulin loading control and it was taken as 1 . Using this value as a standard, the levels of proteins in untreated diabetic control were calculated. The levels of these proteins in the treated wounds were compared to the untreated diabetic control wound and expressed as fold increase. The highest value for $\mathrm{p} 21$ was found in untreated diabetic control and after normalisation with $\gamma$-tubulin loading control it was taken as 1 . The level of p 21 in the treated wounds was compared to the untreated diabetic control wound and expressed as fold decrease. The $\mathrm{pRb}$ protein levels (110 plus $114 \mathrm{kDa}$ bands) were first normalised to the $\gamma$-tubulin; the total $\mathrm{pRb}$ level was taken as $100 \%$. The level of phospho-pRb (114 kDa band) was calculated in the nondiabetic control and untreated and treated diabetic wounds as compared to the total $\mathrm{pRb}$ and expressed as percentage $[13,17]$. The levels of 
TABLE 3: Level of glucose at various time points.

\begin{tabular}{lccc}
\hline Sl. number & $\begin{array}{c}\text { Day of the } \\
\text { experiment }\end{array}$ & $\begin{array}{c}\text { Level of glucose } \\
\text { in control mice } \\
(n=5) ; \\
\text { mg/dL }\end{array}$ & $\begin{array}{c}\text { Level of glucose } \\
\text { in STZ injected } \\
\text { mice }(n=5) ; \\
\text { mg/dL }\end{array}$ \\
\hline 1 & G0 & $131 \pm 2.0$ & $132 \pm 2.1$ \\
2 & G1 & $133 \pm 1.5$ & $131 \pm 1.8$ \\
3 & G7 & $132 \pm 1.8$ & $215 \pm 1.5$ \\
4 & G15 & $132 \pm 2.0$ & $298 \pm 1.9$ \\
5 & G16 & $133 \pm 2.1$ & $323 \pm 2.5$ \\
6 & G22 & $131 \pm 1.7$ & $334 \pm 2.0$ \\
7 & G29 & $132 \pm 2.1$ & $325 \pm 2.3$ \\
\hline
\end{tabular}

$\mathrm{G}$ followed by number in days are as mentioned in Table 2 . The data were calculated from 3 sets of experiments; the standard error of mean was determined and expressed as \pm ; there was no change in the blood glucose level in the growth factors and/or Na-Bu treated diabetic mice as compared to the untreated diabetic mice.

various proteins were obtained from three sets of experiments and the SEM were calculated. These data were analysed using one-way analysis of variance (ANOVA) and Student's $t$-test. The $p$ value of $<0.05$ is considered statistically significant.

\section{Results}

The power analysis showed that data obtained from use of 6 mice in each group was statistically significant.

3.1. Level of Glucose in Control and Treated Mice. The physiologically normal level of 130 to $133 \mathrm{mg} / \mathrm{dL}$ of glucose was present in the nondiabetic control mice. Two days after the last STZ injection, the glucose level was $215 \mathrm{mg} / \mathrm{dL}$ which represented the hyper glycaemic condition. Two weeks after the first injection of STZ, the glucose level was more than $300 \mathrm{mg} / \mathrm{dL}$ which confirmed diabetic condition of these mice and it was maintained for the following 2 to 3 weeks (Tables 2 and 3 ). The experiments were conducted during this period when the mice were in diabetic condition. There was no change in the blood glucose level between the growth factors and/or $\mathrm{Na}-\mathrm{Bu}$ treated diabetic mice as compared to the untreated diabetic control mice (Tables 2 and 3).

3.2. Effect of EGF, PDGF-BB, and Na-Bu on Wound Closure. The percentage of wound closure was measured 14 days after wounding. Individual application of either EGF or PDGFBB partially healed the diabetic wound with $40 \%$ and $55 \%$ of wound closure, respectively. The combination of EGF $+\mathrm{Na}-$ $\mathrm{Bu}$ and PDGF-BB + Na-Bu caused only $35 \%$ and $60 \%$ wound closure, respectively. The combination of EGF + PDGF-BB lead to $55 \%$ wound healing and had no additive effect. The combination of EGF + PDGF-BB for the first two days followed by these growth factors plus $\mathrm{Na}-\mathrm{Bu}$ for the next 12 days produced the best wound healing and more than 95\% wound closure. Topical application of $\mathrm{Na}-\mathrm{Bu}$ alone had deleterious effect on diabetic wound healing process with less than $5 \%$ wound closure. The nondiabetic control wound healed completely by day 14 after wounding. The untreated diabetic control wounds closed less than $10 \%$ and remained unhealed for up to a month after wounding (Table 4).

\subsection{Effect of Growth Factors and Na-Bu on EGF-R Protein} Level. The untreated diabetic wound had trace level of EGF$\mathrm{R}$ protein as compared to the nondiabetic control wound. Topical application of EGF or PDGF-BB or their combination resulted in approximately 4- to 6-fold increase in the level of EGF-R protein in the diabetic wound tissues as compared to the untreated ones and it was statistically significant with $p<0.05$. The peak level of EGF-R protein was found on day 7 after wounding. Combination of EGF plus $\mathrm{Na}-\mathrm{Bu}$ resulted in 2.5-fold decrease in the level of EGF-R on days 7 and 14 as compared to that of EGF application alone. Application of PDGF-BB alone or in combination with EGF resulted in a 2-fold higher level of EGF-R protein on day 1 as compared to that of EGF application. PDGF-BB plus EGF application did not show any additive increase in EGF-R level. PDGF-BB plus Na-Bu or EGF plus PDGF-BB plus Na-Bu did not affect the EGF-R level significantly as compared to the PDGF-BB application. $\mathrm{Na}-\mathrm{Bu}$ application alone had negligible effect on the EGF-R protein level (Figures 1 and 2).

3.4. Effect of Growth Factors and Na-Bu on $\beta-P D G F-R$ Protein Level. The untreated diabetic control wound had trace level of $\beta$-PDGF-R protein as compared to the nondiabetic control. Topical application of EGF and PDGF-BB individually or in combination resulted in approximately 4- to 6-fold increase in the level of $\beta$-PDGF-R protein as compared to the untreated diabetic control wound and it was statistically significant with $p<0.05$. The peak level of $\beta$-PDGF-R protein was found on day 7 after wounding in these cases. Combination of EGF plus $\mathrm{Na}-\mathrm{Bu}$ reduced the level of $\beta$ PDGF-R on days 7 and 14 by 2.5 -fold as compared to that of EGF application alone and it was statistically significant. PDGF-BB plus EGF application did not show any additive increase in $\beta$-PDGF-R level. PDGF-BB plus $\mathrm{Na}-\mathrm{Bu}$ reduced the $\beta$-PDGF-R level by 2 -fold on day 14 as compared to that found on day 7. Application of EGF plus PDGF-BB or EGF plus PDGF-BB plus $\mathrm{Na}-\mathrm{Bu}$ produced the peak level of $\beta$ PDGF-R on day 7 and it did not change significantly on day 14. Application of $\mathrm{Na}-\mathrm{Bu}$ alone caused little change in the level of $\beta$-PDGF-R protein level (Figures 1 and 3).

3.5. Effect of Growth Factors and $\mathrm{Na}-\mathrm{Bu}$ on the Expression of HDAC1 Protein. The nondiabetic control had maximum level of HDAC1 protein on days 1 and 7 and it decreased by half on day 14. The untreated diabetic wound had a 6-fold decrease in the level of HDAC1 protein on days 1,7 , and 14 after wounding as compared to the nondiabetic control. EGF application produced a 6 -fold increase in $\mathrm{HDAC1}$ protein level on day 1 and it gradually decreased to 3-fold on day 14 (Figures 1 and 4). The combination of EGF plus $\mathrm{Na}-\mathrm{Bu}$ lead to a 5-fold decrease in HDAC1 protein level on day 7 as compared to the EGF application and it remained unchanged on day 14. PDGF-BB application alone produced a 6-fold increase in HDAC1 protein level on days 1 and 7 and it 
TABLE 4: Wound closure in control and treated groups.

\begin{tabular}{llc}
\hline Serial number & Growth factor, Na-Bu application & $\begin{array}{c}\text { Percentage wound closure on day 14 } \\
\text { after wounding }\end{array}$ \\
\hline (i) & Nondiabetic untreated control & $100 \%$ \\
\hline (ii) & Diabetic untreated control & $<10 \%$ \\
\hline (iii) & Diabetic wound + 2 mM Na-Bu daily from day 1 to day 14 & $<5 \%$ \\
\hline (iv) & Diabetic wound + 10 ng EGF; daily, day 1 to day 14 & $40 \%$ \\
\hline (v) & Diabetic wound + 10 ng EGF (for first 2 days); 10 ng EGF + 2 mM & $35 \%$ \\
\hline (vi) & Na-Bu (for the following 12 days) & $55 \%$ \\
\hline (vii) & Diabetic wound + 15 ng PDGF-BB daily from day 1 to day 14 & $60 \%$ \\
\hline (viii) & Diabetic wound + 15 ng PDGF-BB (for 2 days); 15 ng PDGF-BB + & $55 \%$ \\
\hline (ix) & 2 mM Na-Bu (for the following 12 days) & \multirow{2}{*}{ Diabetic wound + 10 ng EGF + 15 ng PDGF-BB daily from day 1 to } \\
day 14 & $\begin{array}{l}\text { Diabetic wound + 10 ng EGF + 15 ng PDGF-BB (first 2 days) followed } \\
\text { by the same growth factors + 2 mM Na-Bu daily from day 2 to day 14 }\end{array}$ & $>95 \%$ \\
\hline
\end{tabular}

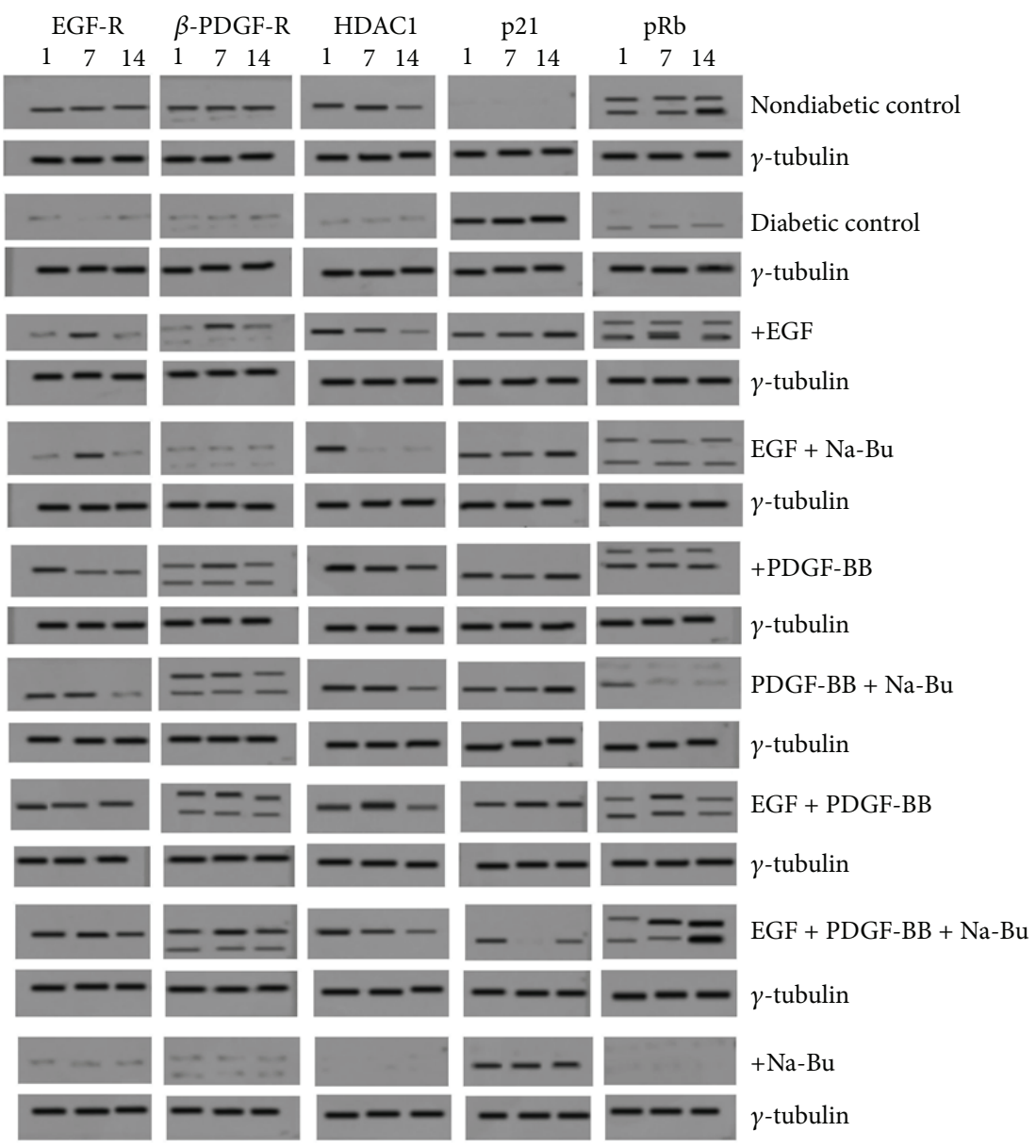

FIGURE 1: Western blot analysis of various proteins in the control and treated wound. The proteins are as marked on the top. The controls and various treatments are given on the right. The number is the days of tissues harvested for protein analysis. 1, day of wounding, 7 , seven days after wounding, and 14, fourteen days after wounding. The $\gamma$-tubulin control is shown separately below each panel. Details of the antibodies and dilutions are given in Table 1. 


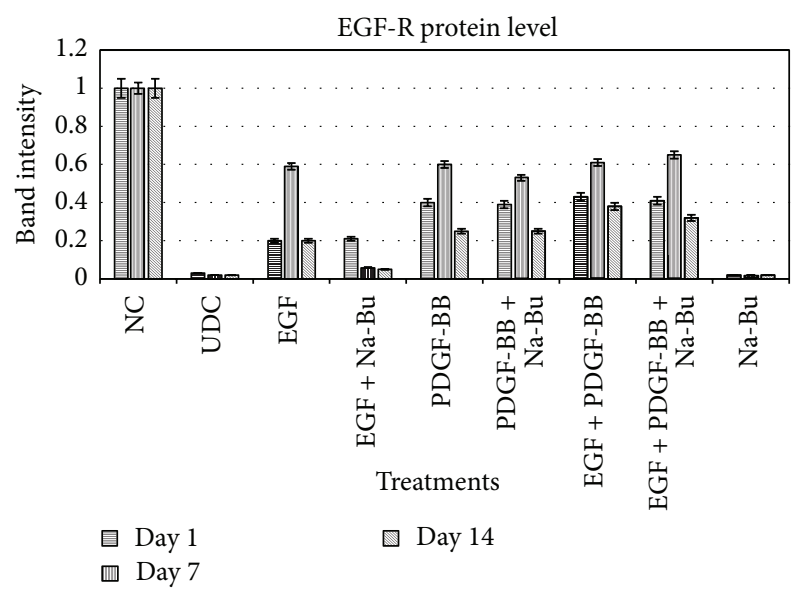

FIGURE 2: Effect of various treatments on the level of EGF-R protein. The various treatments are given in the $x$-axis. The band intensity is given in $y$-axis with Standard Mean Error. The horizontal line is day 1 , vertical line is day 7 , and diagonal line is day 14 after the wounding when the tissue was collected. NC, normal control; UDC, untreated diabetic control; the growth factor and $\mathrm{Na}-\mathrm{Bu}$ treatments are as given below each panel.

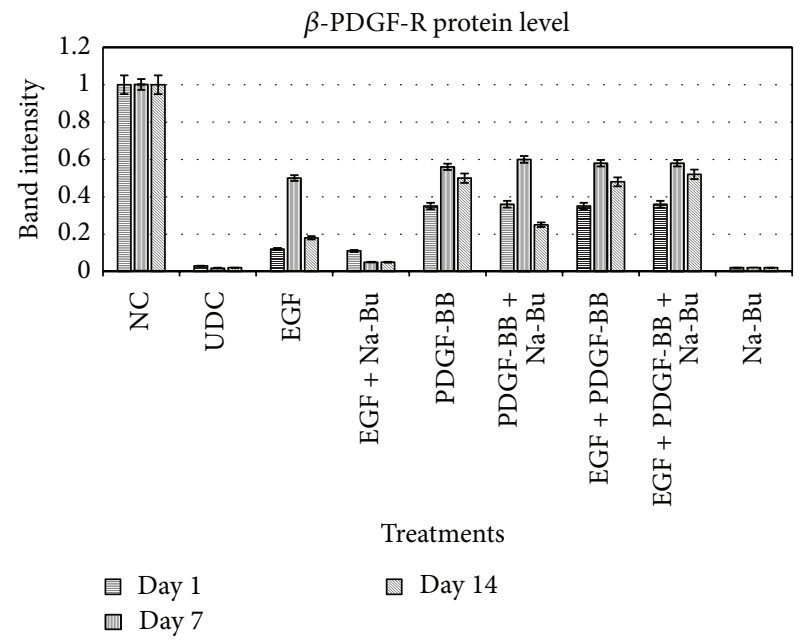

FIGURE 3: Effect of various treatments on the level of $\beta$-PDGF-R protein. The various treatments are given in the $x$-axis. The band intensity is given in $y$-axis with Standard Mean Error. The horizontal line is day 1 , vertical line is day 7 , and diagonal line is day 14 after the wounding when the tissue was collected. NC, normal control; UDC, untreated diabetic control; the growth factor and $\mathrm{Na}-\mathrm{Bu}$ treatments are as given below each panel.

was statistically significant with a $p<0.05$ and on day 14 it decreased slightly. Application of PDGF-BB plus EGF produced approximately 6 -fold increase in $\mathrm{HDAC1}$ protein level on days 1 and 7 but it decreased to 3 -fold on day 14. The combination PDGF-BB plus Na-Bu or EGF plus PDGF-BB plus $\mathrm{Na}-\mathrm{Bu}$ caused a peak level of 6 -fold increase in HDAC1 protein on day 1 and it gradually decreased to approximately 2- to 3-fold on day 14. The Na-Bu treated diabetic wound had no effect on the level of $\mathrm{HDACl}$ protein (Figures 1 and 4).

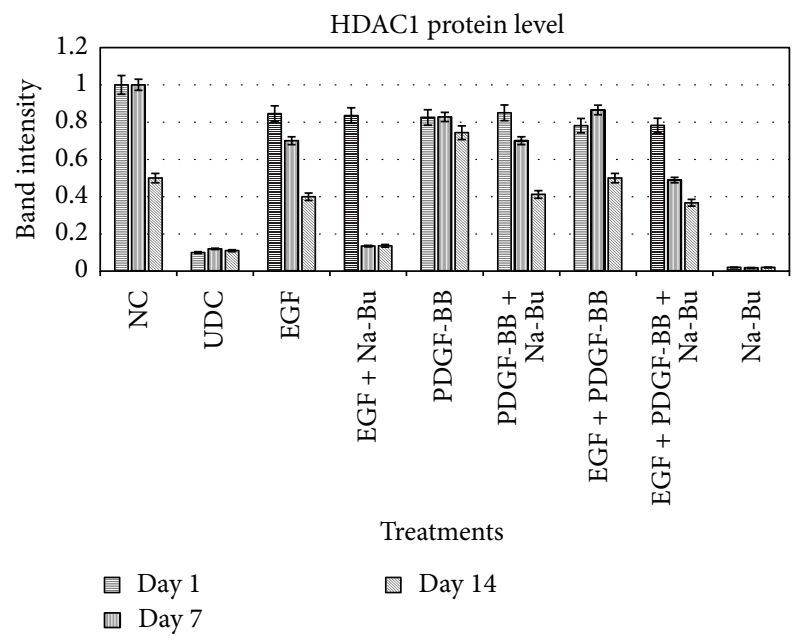

FIGURE 4: Effect of various treatments on the level of HDAC1 protein. The various treatments are given in the $x$-axis. The band intensity is given in $y$-axis with Standard Mean Error. The horizontal line is day 1 , vertical line is day 7 , and diagonal line is day 14 after the wounding when the tissue was collected. NC, normal control; UDC, untreated diabetic control; the growth factor and $\mathrm{Na}-\mathrm{Bu}$ treatments are as given below each panel.

3.6. Effect of Growth Factors and Na-Bu on p21 Protein Expression. The diabetic wound tissue had approximately 6 -fold increase in the level of p21 protein as compared to the nondiabetic control wound. Topical application of EGF or PDGF$\mathrm{BB}$ and their combination with $\mathrm{Na}-\mathrm{Bu}$ reduced the $\mathrm{p} 21$ protein level to approximately 2.5 -fold on days 1 and 7 and 1.5 -fold on day 14 as compared to the untreated diabetic wound and it was statistically significant with $p<0.05$. The combination of EGF plus PDGF-BB reduced the p21 protein level to half of that found in untreated diabetic control wound and this level was maintained on days 1,7 , and 14 after wounding. The combination of EGF plus PDGF-BB plus $\mathrm{Na}-\mathrm{Bu}$ caused a drastic 5- and 4-fold decrease in the level of p21 protein on days 7 and 14, respectively, as compared to the untreated diabetic control wound and it was statistically significant with $p<0.05$. The $\mathrm{p} 21$ protein level in the $\mathrm{Na}-$ $\mathrm{Bu}$ treated wounds was almost similar to that of untreated diabetic wound (Figures 1 and 5).

3.7. Effect of Growth Factors and $\mathrm{Na}-\mathrm{Bu}$ on the Level and Phosphorylation of $p R b$. The nondiabetic control wound had approximately 4 -fold higher level of total $\mathrm{pRb}$ and $50 \%$ of it was found in phosphorylated form on days 1 and 7 as compared to the untreated diabetic control. On day 14, only $20 \%$ of total pRb was found as phosphorylated form and the remaining $80 \%$ was hypophosphorylated. The untreated diabetic control had about $5 \%$ of total pRb in phosphorylated form. EGF or PDGF-BB application resulted in a 3- to 5-fold increase in the level of total $\mathrm{pRb}$ protein and approximately $20 \%$ of it was found in phosphorylated form in the diabetic wound as compared to the untreated diabetic control (Figures 1 and 6). Application of EGF plus Na-Bu or PDGF-BB plus $\mathrm{Na}-\mathrm{Bu}$ did not result in any significant change in the level of total $\mathrm{pRb}$ protein in the diabetic wound as compared to 


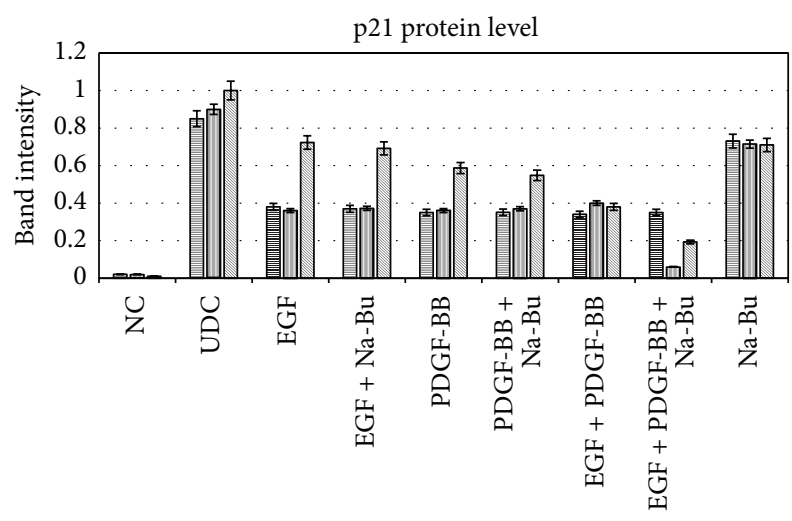

Treatments

$$
\begin{array}{ll}
\square \text { Day } 1 & \square \text { Day } 14 \\
\square \text { Day } 7 &
\end{array}
$$

FIGURE 5: Effect of various treatments on the level of p21 protein. The various treatments are given in the $x$-axis. The band intensity is given in $y$-axis with Standard Mean Error. The horizontal line is day 1 , vertical line is day 7 , and diagonal line is day 14 after the wounding when the tissue was collected. NC, normal control; UDC, untreated diabetic control; the growth factor and $\mathrm{Na}-\mathrm{Bu}$ treatments are as given below each panel.

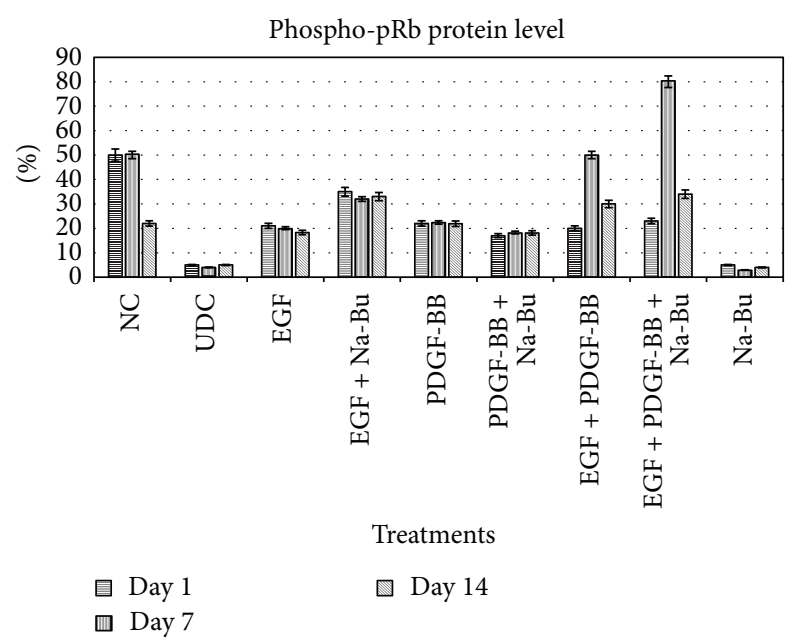

Figure 6: Effect of various treatments on the percentage of phosphorylated $\mathrm{pRb}$ protein. The various treatments are given in the $x$-axis. The percentage of $\mathrm{pRb}$ is given in $y$-axis with Standard Mean Error. The horizontal line is day 1 , vertical line is day 7 , and diagonal line is day 14 after the wounding when the tissue was collected. NC, normal control; UDC, untreated diabetic control; the growth factor and $\mathrm{Na}$ $\mathrm{Bu}$ treatments are as given below each panel.

the individual growth factor application. Approximately 20 to $35 \%$ of the total $\mathrm{pRb}$ was found in phosphorylated form with the individual growth factors plus $\mathrm{Na}-\mathrm{Bu}$ combination. The combination of EGF plus PDGF-BB resulted in a 4to 5 -fold increase in total $\mathrm{pRb}$ protein and 30 to $50 \%$ of it existed in phosphorylated form. The combination of EGF plus PDGF-BB plus Na-Bu increased the level of total $\mathrm{pRb}$ by approximately 6- to 7-fold on days 7 and 14 after treatment. More importantly with this combination approximately $80 \%$ of total $\mathrm{pRb}$ remained in phosphorylated form on day 7. On day 14, approximately $70 \%$ of total $\mathrm{pRb}$ existed in hypophosphorylated form and it was statistically significant. It has to be noted that the $\mathrm{Na}-\mathrm{Bu}$ treated wound had less than $5 \%$ of $\mathrm{pRb}$ in phosphorylated form (Figures 1 and 6).

\section{Discussion}

The process of wound healing requires a highly regulated mechanism at the molecular level and may be divided into three phases: (i) inflammation, (ii) cell proliferation, and (iii) cell differentiation/maturation [18, 19]. Topical application of EGF plus PDGF-BB produced the best wound healing in acute cutaneous wound healing model in mice [3-5]. These growth factors enhanced wound repair process through increased expression of their corresponding receptor mRNAs, proteins, and receptor protein phosphorylation [4, 5]. Delayed or defective wound healing causes a significant morbidity in diabetic patients [20, 21]. Reduced levels of a number of growth factors including PDGFs and EGF have been shown in the chronic wound as compared to the acute wound [22] and it is proposed that destruction of growth factors by proinflammatory cytokines is responsible for such reduction [23]. Therefore, the effect of topically applied growth factors was tested by many groups in chronic as well as diabetic wound healing, some of which produced promising results. For example, topical application of EGF helped diabetic wound healing in experimental animal model [7] and in patients with foot ulcers [6]. Application of PDGF improved experimental diabetic wound healing $[8,9]$. Both EGF and PDGFs aided tissue granulation at the wound site $[10,24]$. Data from the present study shows that daily topical application of growth factors EGF and PDGF-BB at the immediate early stages, either individually or in combination, partially helped the diabetic wound healing process. This is in agreement with previous studies where these growth factors have shown to be beneficial in the diabetic wound healing in human and animal models [6-10].

The reduced levels of EGF-R and $\beta$-PDGF-R in the untreated diabetic wound and its concomitant increase in the growth factor treated wound (Figures 1, 2, and 3) indicate that such an increase could have partially aided the diabetic wound healing (Table 4). The reduced efficacy of EGF plus $\mathrm{Na}-\mathrm{Bu}$ is due to drastic reduction in the levels of EGF-R and $\beta$-PDGF-R (Figures 1, 2, and 3) as these proteins are necessary for cell migration and proliferation during wound healing process $[25,26]$. Previous report showed no synergy between PDGF-BB and EGF in diabetic wound healing in mice [27]. Our data confirms this report as this combination did not improve the diabetic wound closure and failed to produce additive increase in receptor protein levels (Figures 1,2 , and 3 ). It has been shown that $\mathrm{Na}-\mathrm{Bu}$ treatment leads to withdrawal of cells from cell cycle [28] and the current data confirms this report as $\mathrm{Na}-\mathrm{Bu}$ caused less than $5 \%$ wound closure (Table 4) perhaps due to withdrawal of most cells from cell cycle at the wound site.

Sodium butyrate induces cell differentiation [13] and inhibits HDAC1 $[14,15]$. HDAC have essential, pleotropic roles in cell proliferation and $\mathrm{HDACl}$ prevents expression of 
antiproliferative genes in cycling cells [29]. HDAC1 has a regulatory role in stem cell renewal by maintaining expression of key pluripotent transcription factors [30]. HDAC is essential for unrestricted cell proliferation by repressing selective cell cycle inhibitors and HDAC1 represses the CDK inhibitor $\mathrm{p} 21$ [29]. The partial wound healing in diabetic mice caused by the application of EGF and PDGF-BB appears to be through increased expression of HDACl (Figures 1 and 4) and decreased p21 protein expression (Figure 5). The p21 protein is an inhibitor of CDK2/cyclin complex and CDK2/ cyclin (cyclins $\mathrm{D}$ and $\mathrm{E}$ ) complexes phosphorylate $\mathrm{pRb}$ protein. Phospho-pRb is necessary for G1 to S-phase transition of cells during cell cycle [31]. Thus, it appears that higher level of HDAC1, drastic downregulation of p21 protein, and increased level of total $\mathrm{pRb}$ with increased percentage of phosphorylated $\mathrm{pRb}$ are necessary for efficient cell proliferation at the initial stages of wound healing in diabetic cases (Figures 1, 4, 5, and 6). Increased level of total $\mathrm{pRb}$ and increased percentage of hypophosphorylated form of $\mathrm{pRb}$ were reported in $\mathrm{Na}-\mathrm{Bu}$ induced differentiation in cultured human colon cancer cell line HT29 [13]. Our data shows that increased percentage of hypophosphorylated $\mathrm{pRb}$ in the later stages of wound healing could be necessary for cell differentiation in diabetic cases (Figures 1 and 6).

Exudate from nonhealing diabetic wound had numerous mediators characteristic for persistent inflammatory and tissue destructive response as compared to the healing wound which had many differentiation markers [32]. High levels of serine protease inhibitor, SerpinB3, were reported as a biomarker for successful wound healing in diabetic patients [33]. Erythropoietin is a novel repurposed drug for diabetic wound healing which promotes cell differentiation [34]. Thus, it appears that, after initial growth factor application that promotes cell proliferation, addition of a cell differentiation factor, $\mathrm{Na}-\mathrm{Bu}$, is essential at later stages for normal diabetic wound healing. In addition to degradation of growth factors, the proinflammatory cytokines [23] could also degrade differentiation factors thereby preventing or delaying cellular differentiation. Growth factors-induced cell proliferation when not accompanied by cell differentiation could perhaps lead to exhaustion of the number of dividing cells which in turn could lead to unhealed or partially healed diabetic wound.

Therefore, addition of exogenous differentiation agent(s) might also be necessary for efficient diabetic wound healing process. However, our data indicates that the exogenous applications of cell proliferation agents such as growth factors and cell differentiation agents such as $\mathrm{Na}$ - $\mathrm{Bu}$ should be done in a sequential, sustained, and time-bound manner (Table 4). The application of growth factors should be performed immediately after wounding in order to facilitate cell migration to the wound site and cell proliferation and it should precede the application of $\mathrm{Na}-\mathrm{Bu}$ (Table 4). Once the growth factors set the cell proliferation process in motion, the newly divided cells need to be differentiated for effective wound closure. Therefore, the differentiation agent should be provided at a little later stages in order to achieve maximum benefit during diabetic wound healing process. Addition of differentiation agent such as $\mathrm{Na}-\mathrm{Bu}$ alone at the immediate early stages of the wound healing process is deleterious for the wound healing process (Table 4; Figure 1) because $\mathrm{Na}-\mathrm{Bu}$ could prevent cell proliferation [35] and induce apoptosis as observed in cultured cells [36].

The concentration of Na-Bu used in the present study is $2 \mathrm{mM}$ which is half of that of its physiological concentration of $5 \mathrm{mM}$ [37]. The subphysiological concentration of $2 \mathrm{mM}$ $\mathrm{Na}-\mathrm{Bu}$ used in our study could aid cell differentiation and perhaps could not totally block the growth factor aided cell cycle to proceed so as to accomplish normal healing of diabetic wound. Topical application of growth factors and/or Na$\mathrm{Bu}$ did not affect the blood glucose level in the treated mice as compared to the untreated ones. These applications did not cause any side effects either at the wound site or to the whole animal (unpublished observation).

\section{Conclusions}

Currently the use of recombinant human PDGF-BB and Becaplermin gel as an adjuvant therapy is approved by the Food and Drug Administration to treat diabetic wound [38]. It is sold with a commercial name "REGRANEX" with a warning that "people who use 3 or more tubes of REGRANEX Gel may have increased risk of death from cancer" (http:// www.regranex.com/patient/). The results from our experiments suggest that addition of a cell differentiation agent, $\mathrm{Na}-$ $\mathrm{Bu}$, could counter such carcinogenic side effects of PDGF-BB and also EGF. Sodium butyrate also could minimise the carcinogenic effect of PDGF-BB in the commercially available REGRANEX gel if a diabetic patient has to use more than 2 tubes to treat the wound. It is conceivable that only cell proliferation is happening in some of these diabetic wounds treated with REGRANEX with minimal or no cell differentiation. Therefore, addition of sodium butyrate in the $3 r d$ or even in the 2nd tube of REGRANEX gel could help maximise cell differentiation in addition to cell proliferation leading to effective diabetic wound healing. Such an addition of sodium butyrate could also minimise or reduce the potential carcinogenic effect of PDGF-BB. It could do so because sodium butyrate is an anti-cell proliferative agent and it is also known to induce apoptotic cell death in cultured cancer cells $[35,36]$. Thus, the topical application of combination of EGF plus PDGF-BB along with a differentiation inducing agent $(\mathrm{Na}-\mathrm{Bu})$ may eventually be considered for clinical treatment and management of various human wounds and burns.

\section{Conflict of Interests}

The authors declare that there is no conflict of interests regarding the publication of this paper.

\section{Authors' Contribution}

Rohini Keshava and Rajalakshmi Gope made equal contribution.

\section{Acknowledgments}

The authors thank Dr. J. Sureshchandra, Senior Veterinary Officer, and Mr. K. S. Yogeesh, Central Animal Research 
Facility, NIMHANS, Bangalore, for their kind cooperation. The authors also thank Dr. D. K. Subbakrishna for his help with statistical data analysis and NIMHANS for providing infrastructure and other support to carry out the experiments. Rohini Keshava is a Postdoctoral Research Fellow of Kothari foundation (UGC).

\section{References}

[1] W. J. Jeffcoate and K. G. Harding, "Diabetic foot ulcers," The Lancet, vol. 361, no. 9368, pp. 1545-1551, 2003.

[2] A. J. Boulton, L. Vileikyte, G. Ragnarson-Tennvall, and J. Apelqvist, "The global burden of diabetic foot disease," The Lancet, vol. 366, no. 9498, pp. 1719-1724, 2005.

[3] R. Gope, "The effect of epidermal growth factor \& plateletderived growth factors on wound healing process," Indian Journal of Medical Research, vol. 116, no. 4, pp. 201-206, 2002.

[4] M. L. Gope and R. Gope, "Topically applied EGF and PDGFs affect positively the co-ordinate expression of EGF and PDGF receptor genes during acute cutaneous wound-healing process," Current Science, vol. 92, no. 5, pp. 618-627, 2007.

[5] M. L. Gope and R. Gope, "Tyrosine phosphorylation of EGF-R and PDGF-R proteins during acute cutaneous wound healing process in mice," Wound Repair and Regeneration, vol. 17, no. 1, pp. 71-79, 2009.

[6] M. W. Tsang, W. K. R. Wong, C. S. Hung et al., "Human epidermal growth factor enhances healing of diabetic foot ulcers," Diabetes Care, vol. 26, no. 6, pp. 1856-1861, 2003.

[7] S. Dogan, S. Demirer, I. Kepenekci et al., "Epidermal growth factor-containing wound closure enhances wound healing in non-diabetic and diabetic rats," International Wound Journal, vol. 6, no. 2, pp. 107-115, 2009.

[8] R. L. Brown, M. P. Breeden, and D. G. Greenhalgh, "PDGF and TGF- $\alpha$ act synergistically to improve wound healing in the genetically diabetic mouse," Journal of Surgical Research, vol. 56, no. 6, pp. 562-570, 1994.

[9] D. G. Greenhalgh, K. H. Sprugel, M. J. Murray, and R. Ross, "PDGF and FGF stimulate wound healing in the genetically diabetic mouse," The American Journal of Pathology, vol. 136, no. 6, pp. 1235-1246, 1990.

[10] G. R. Grotendorst, G. R. Martin, D. Pencev, J. Sodek, and A. K. Harvey, "Stimulation of granulation tissue formation by platelet-derived growth factor in normal and diabetic rats," The Journal of Clinical Investigation, vol. 76, no. 6, pp. 2323-2329, 1985.

[11] A. A. Like and A. A. Rossini, "Streptozotocin-induced pancreatic insulitis: new model of diabetes mellitus," Science, vol. 193, no. 4251, pp. 415-417, 1976.

[12] M. Song, B. Xia, and J. Li, "Effects of topical treatment of sodium butyrate and 5-aminosalicylic acid on expression of trefoil factor 3 , interleukin $1 \beta$, and nuclear factor $\kappa \mathrm{B}$ in trinitrobenzene sulphonic acid induced colitis in rats," Postgraduate Medical Journal, vol. 82, no. 964, pp. 130-135, 2006.

[13] R. Gope and M. L. Gope, "Effect of sodium butyrate on the expression of retinoblastoma (RB1) and P53 gene and phosphorylation of retinoblastoma protein in human colon tumor cell line HT29.", Cellular and Molecular Biology, vol. 39, no. 6, pp. 589-597, 1993.

[14] T. Davis, C. Kennedy, Y.-E. Chiew, C. L. Clarke, and A. Defazio, "Histone deacetylase inhibitors decrease proliferation and modulate cell cycle gene expression in normal mammary epithelial cells," Clinical Cancer Research, vol. 6, no. 11, pp. 43344342, 2000.

[15] Y. Karasawa and S. Okisaka, "Inhibition of histone deacetylation by butyrate induces morphological changes in Y79 retinoblastoma cells," Japanese Journal of Ophthalmology, vol. 48, no. 6, pp. 542-551, 2004.

[16] D. Barham and P. Trinder, "An improved color reagent for the determination of blood glucose by the oxidase system," Analyst, vol. 97, no. 1151, pp. 142-145, 1972.

[17] R. Mitra, B. Indira Devi, M. L. Gope, D. K. Subbakrishna, and R. Gope, "Sodium butyrate modulates pRb phosphorylation and induces cell death in human vestibular schwannomas in vitro," Indian Journal of Experimental Biology, vol. 50, no. 1, pp. 19-27, 2012.

[18] P. Martin, "Wound healing—aiming for perfect skin regeneration," Science, vol. 276, no. 5309, pp. 75-81, 1997.

[19] A. J. Singer and R. A. F. Clark, "Cutaneous wound healing," The New England Journal of Medicine, vol. 341, no. 10, pp. 738-746, 1999.

[20] R. S. Most and P. Sinnock, "The epidemiology of lower extremity amputations in diabetic individuals," Diabetes Care, vol. 6, no. 1, pp. 87-91, 1983.

[21] G. E. Reiber, B. A. Lipsky, and G. W. Gibbons, "The burden of diabetic foot ulcers," The American Journal of Surgery, vol. 176, no. 2, supplement 2, pp. 5S-10S, 1998.

[22] D. M. Cooper, E. Z. Yu, P. Hennessey et al., "Determination of endogenous cytokines in chronic wounds," Annals of Surgery, vol. 219, no. 6, pp. 688-692, 1994.

[23] N. T. Bennett and G. S. Schultz, "Growth factors and wound healing. Part II. Role in normal and chronic wound healing," The American Journal of Surgery, vol. 166, no. 1, pp. 74-81, 1993.

[24] E. K. LeGrand, T. C. Kiorpes, J. F. Burke, and D. E. Costa, "Dose responsive effects of PDGF-BB, PDGF-AA, EGF, and bFGF on granulation tissue in a Guinea pig partial thickness skin excision model," Growth Factors, vol. 8, no. 4, pp. 307-314, 1993.

[25] G. L. Brown, L. B. Nanney, J. Griffen et al., "Enhancement of wound healing by topical treatment with epidermal growth factor," The New England Journal of Medicine, vol. 321, no. 2, pp. 76-79, 1989.

[26] C.-H. Heldin and B. Westermark, "Mechanism of action and in vivo role of platelet-derived growth factor," Physiological Reviews, vol. 79, no. 4, pp. 1283-1316, 1999.

[27] R. L. Brown, M. P. Breeden, and D. G. Greenhalgh, "PDGF and TGF- $\alpha$ act synergistically to improve wound healing in the genetically diabetic mouse," Journal of Surgical Research, vol. 56, no. 6, pp. 562-570, 1994.

[28] S. Leon Carrion, C. H. Sutter, and T. R. Sutter, "Combined treatment with sodium butyrate and PD153035 enhances keratinocyte differentiation," Experimental Dermatology, vol. 23, no. 3, pp. 211-214, 2014.

[29] G. Lagger, D. O'Carroll, M. Rembold et al., "Essential function of histone deacetylase 1 in proliferation control and CDK inhibitor repression," The EMBO Journal, vol. 21, no. 11, pp. 26722681, 2002.

[30] S. Jamaladdin, R. D. W. Kelly, L. O’Regan et al., "Histone deacetylase (HDAC) 1 and 2 are essential for accurate cell division and the pluripotency of embryonic stem cells," Proceedings of the National Academy of Sciences of the United States of America, vol. 111, no. 27, pp. 9840-9845, 2014.

[31] M. D. Planas-Silva and R. A. Weinberg, "The restriction point and control of cell proliferation," Current Opinion in Cell Biology, vol. 9, no. 6, pp. 768-772, 1997. 
[32] S. A. Eming, M. Koch, A. Krieger et al., "Differential proteomic analysis distinguishes tissue repair biomarker signatures in wound exudates obtained from normal healing and chronic wounds," Journal of Proteome Research, vol. 9, no. 9, pp. 47584766, 2010.

[33] G. P. Fadini, M. Albiero, R. Millioni et al., "The molecular signature of impaired diabetic wound healing identifies serpinB3 as a healing biomarker," Diabetologia, vol. 57, no. 9, pp. 1947-1956, 2014.

[34] S. Hamed, C. L. Bennett, C. Demiot, Y. Ullmann, L. Teot, and A. Desmoulière, "Erythropoietin, a novel repurposed drug: an innovative treatment for wound healing in patients with diabetes mellitus," Wound Repair and Regeneration, vol. 22, no. 1, pp. 23-33, 2014.

[35] J. Kruh, "Effects of sodium butyrate, a new pharmacological agent, on cells in culture," Molecular and Cellular Biochemistry, vol. 42, no. 2, pp. 65-82, 1981.

[36] R. Mitra, R. Keshava, J. Mathivanan, V. Vikas, B. Indira Devi, and R. Gope, "Bay 61-3606, CDKi, and sodium butyrate treatments modulate $\mathrm{p} 53$ protein level and its site-specific phosphorylation in human vestibular schwannomas in vitro," Journal of Cancer Research, vol. 2014, Article ID 249354, 9 pages, 2014.

[37] N. Burger-van Paassen, A. Vincent, P. J. Puiman et al., "The regulation of intestinal mucin MUC2 expression by short-chain fatty acids: Implications for epithelial protection," Biochemical Journal, vol. 420, no. 2, pp. 211-219, 2009.

[38] Food and Drug Administration, FDA Talk Paper, U.S. Department of Health and Human Services, Rockville, Md, USA, 1997. 

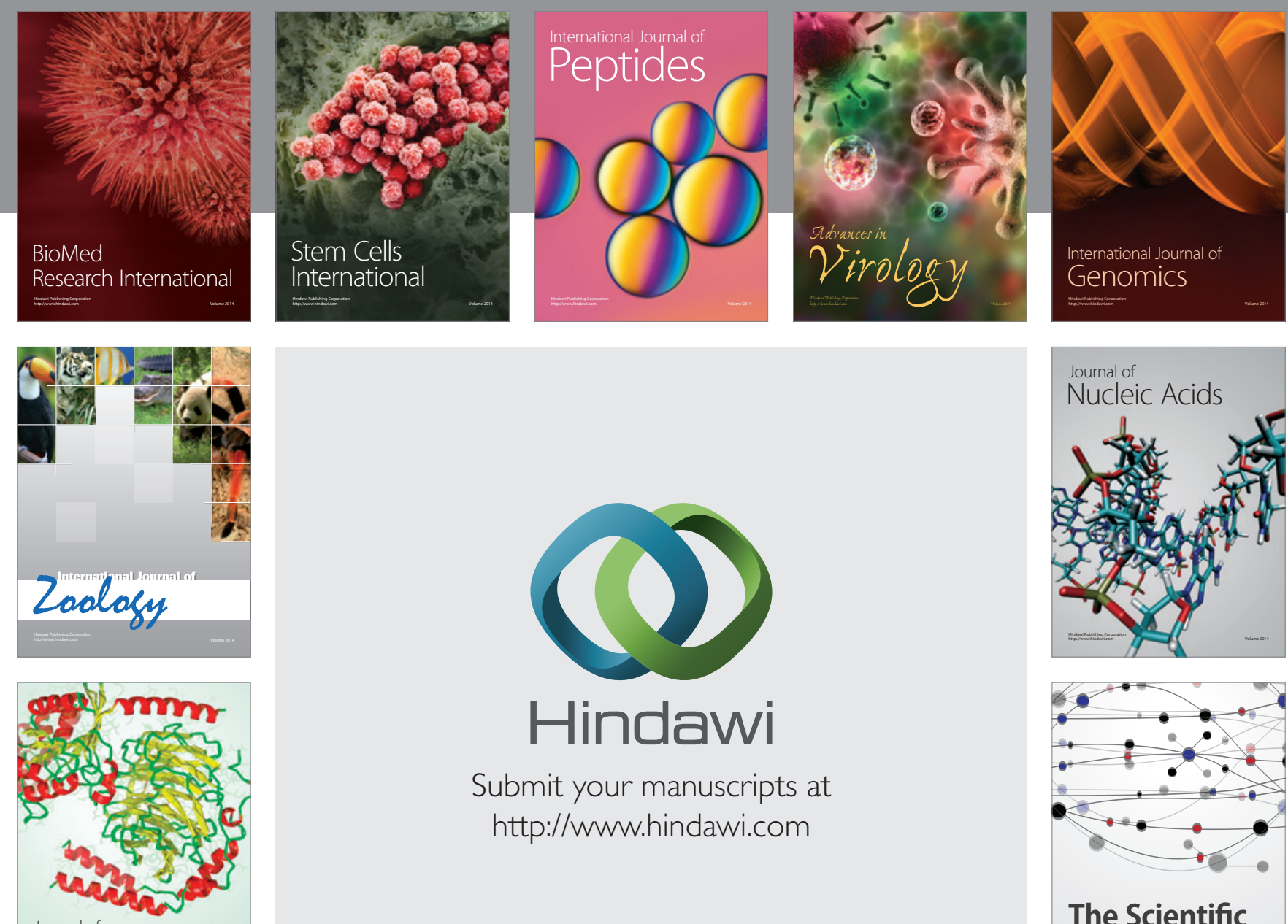

Submit your manuscripts at

http://www.hindawi.com

Journal of
Signal Transduction
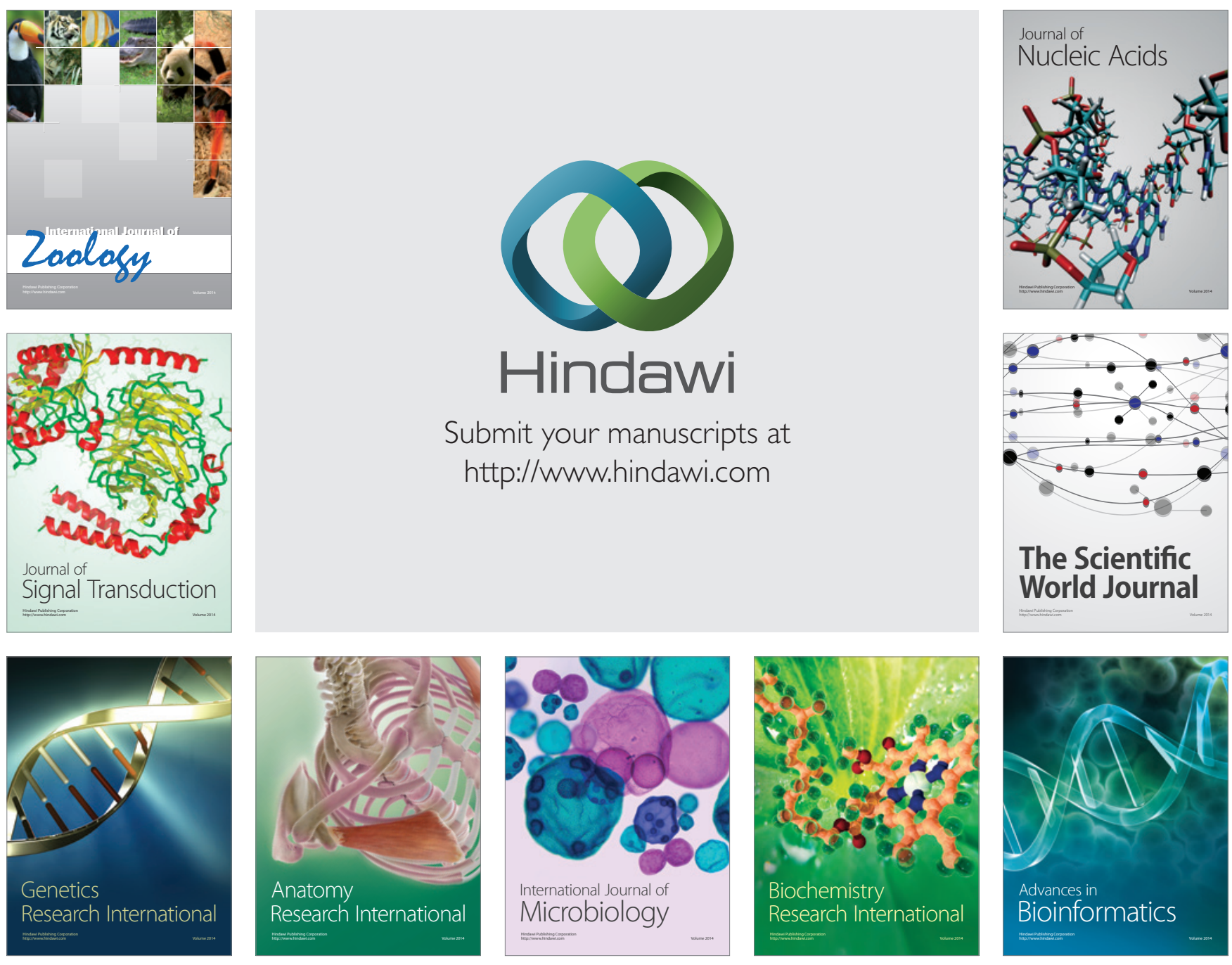

The Scientific World Journal
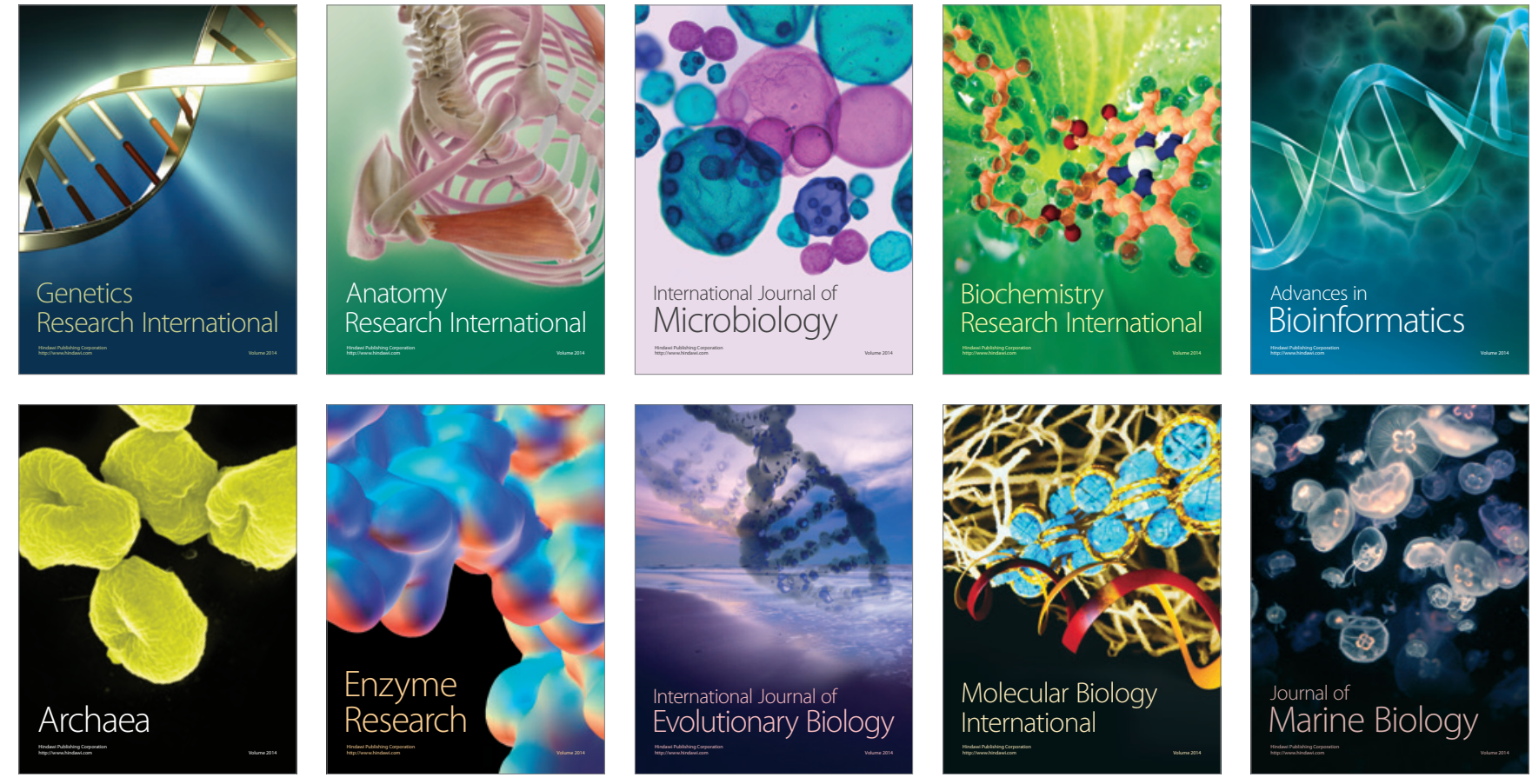